\title{
SSPN wt Allele
}

National Cancer Institute

\section{Source}

National Cancer Institute. SSPN wt Allele. NCI Thesaurus. Code C52378.

Human SSPN wild-type allele is located in the vicinity of 12 p11.2 and is approximately 37

$\mathrm{kb}$ in length. This allele, which encodes sarcospan protein, plays a role in plasma

membrane organization between the cytoskeleton and the extracellular matrix. 